\title{
Mixed cryoglobulinaemia: An important but frequently unrecognized and underestimated HCV-related condition in the real life practice
}

\section{Dear Editor:}

We read with interest the paper "Effectiveness and cost of hepatitis $C$ virus cryoglobulinaemia vasculitis treatment: from interferon-based to direct acting antivirals era", ${ }^{1}$ and we feel that the combination of effectiveness with a cost analysis is original and increases the awareness about patients with Mixed Cryoglobulinaemia (MC).

A dedicated approach, focusing on the diagnosis and on the impact of treatment of MC, have been included within the Italian Platform for the Study of Viral Hepatitis Therapies (PITER). ${ }^{2}$ Of the $8005 \mathrm{HCV}+$ patients enrolled in PITER, only 1678 (21\%) have been evaluated for the presence of MC, that was shown in 771 (46\%) patients, 266 (35\%) of whom were symptomatic (cryoglobulinaemic vasculitis -CryoVasor MC syndrome-MCS-). Among the centres that considered MC, $64 \%$ evaluated cryoglobulinaemia only if MC was clinically suspected. Cryocrit was determined at admission based on Complement/ Rheumatoid Factor (RF) levels or only in case of RF positivity $(58 \%$ and $42 \%$ of the centres respectively). Cryo testing was not adequate in $39 \%$ of the centres. These results, showed the real-life variability in the diagnostic approach to $M C$, suggesting, on the one hand, that $M C$ prevalence in $\mathrm{HCV}+$ individuals is generally underestimated, and, on the other hand, that the percentage of MC patients with CryoVas was probably overestimated in centres where $\mathrm{MC}$ is not routinely assessed.

In the paper of Cacoub et al., the major studies that have reported a very good clinical profile for CryoVas treatment with DAAs are cited. The preliminary prospective results from 129 CryoVas treated patients included in PITER confirm the high clinical, immunological and virological effectiveness of DAA-based therapy in a large representative sample of these patients ${ }^{3}$ (Table 1).

Excluding the cost of antiviral treatment, the costs of CryoVas treatment cited in the study of Cacoub et al. are higher than previous

TAB LE 1 Clinical Response of CryoVas patients achieving SVR12

\begin{tabular}{|c|c|c|}
\hline $\begin{array}{l}\text { Disappearance or improve- } \\
\text { ment of all symptoms }\end{array}$ & $\begin{array}{l}61 \text { patients } \\
(48 \%)\end{array}$ & $\begin{array}{l}\text { Complete } \\
\text { response }\end{array}$ \\
\hline $\begin{array}{l}\text { Improvement of more than } \\
50 \% \text { of symptoms }\end{array}$ & $\begin{array}{l}52 \text { patients } \\
(41 \%)\end{array}$ & $\begin{array}{l}\text { Partial clinical } \\
\text { response }\end{array}$ \\
\hline $\begin{array}{l}\text { Improvement in less than } 50 \% \\
\text { of symptoms }\end{array}$ & 12 patients (9\%) & Non-Response \\
\hline Complete persistence & 4 patients $(3 \%)$ & \\
\hline
\end{tabular}

estimates for different severities of liver disease and also higher than the cost of patients with hospital admission because of liver failure complications. ${ }^{4,5}$ In conclusion, available data stress the important economic burden of this syndrome and emphasize the importance of better management in order to decrease the clinical and economic consequences.

\section{FINANCIAL SUPPORT}

None for all the authors.

\section{CONFLICT OF INTEREST}

The authors do not have any disclosures to report.

$$
\begin{aligned}
& \text { Loreta A. Kondili }{ }^{1} \text { iD } \\
& \text { Stefano Vella }{ }^{1} \\
& \text { Anna Linda Zignego }{ }^{2} \\
& \text { On behalf of PITER collaborating Group }{ }^{3}
\end{aligned}
$$

${ }^{1}$ Center for Global Health, Istituto Superiore di Sanità, Rome, Italy

${ }^{2}$ Interdepartmental Hepatology Center MaSVE, Department of Experimental and Clinical Medicine, University of Florence, Florence, Italy ${ }^{3}$ PITER Collaborating Group available on www.iss.it/piter

\section{REFERENCES}

1. Cacoub P, Vautier M, Desbois AC, Lafuma A, Saadoun D. Effectiveness and cost of hepatitis $C$ virus cryoglobulinemia vasculitis treatment: from interferon-based to direct acting antivirals era. Liver Int. 2017;37: 1805-1813.

2. Kondili LA, Vella S, PITER Collaborating Group. PITER: an ongoing nationwide study on the real-life impact of direct acting antiviral based treatment for chronic hepatitis C in Italy. Dig Liver Dis. 2015;47:741-743.

3. Zignego AL, Ramos-Casals M, Ferri C, et al. International therapeutic guidelines for patients with HCV-related extrahepatic disorders. A multidisciplinary expert statement. Autoimmun Rev. 2017;16:523-541.

4. Kondili LA, Monti M, Gaeta GB., et al. on behalf of PITER Collaborating Group. Diagnostic and therapeutic approaches of mixed cryoglobulinemia in PITER (Piattaforma Italiana per lo studio della Terapia delle Epatiti viRali) cohort. J Hepatol. 2017;66:S535.FRI-279

5. Schwarzinger M, Deuffic-Burban S, Mallet V, et al. Lifetime costs attributable to chronic hepatitis $C$ from the French healthcare perspective. J Hepatol. 2013;58:S21-S22. 